\title{
DYSKURSYWIZM ARCHEOLOGII WEDLUG HENRYKA MAMZERA: OGRANICZENIA ORIENTACJI KONSTRUKTYWISTYCZNEJ A MIT ETNICZNY W ARCHEOLOGII
}

\author{
DISCOURSE OF ARCHAEOLOGY ACCORDING \\ TO HENRYK MAMZER: LIMITATIONS OF CONSTRUCTIVIST \\ ORIENTATION AND THE ETHNIC MYTH IN ARCHAEOLOGY
}

\author{
Sebastian Urbaniak \\ https://orcid.org/0000-0002-9334-5192 \\ Instytut Filozofii, Instytut Literatury i Nowych Mediów \\ Wydział Humanistyczny \\ Uniwersytet Szczeciński, Szczecin, Poland \\ wernyhorys@gmail.com
}

\begin{abstract}
Henryk Mamzer's conception is an interesting new contribution to the development of socalled constructivist approaches in archaeology. As such it is a good example of the basic assumptions underlying its theory and methodology. In this article I will argue with some basic assumptions of Mamzer's theory, trying to show that constructivism doesn't rescue archaeology from the problems, which he would like to avoid. In fact, it deals with the same problems.
\end{abstract}

KEY WORDS: Henryk Mamzer, constructivism, Michael Foucault, ethnicity, theory of archaeology

Przez zastosowanie pojęcia „dyskursu” Henryk Mamzer podejmuje próbę przeformułowania celów badawczych archeologii jako dyscypliny humanistycznej. Punktem wyjścia jego rozważań w tym względzie jest zwrócenie uwagi na „metaforę archeologiczną", zastosowaną m.in. przez Michela Foucaulta (1977, 2002). Archeologia pojmowana metaforycznie „oznacza coś więcej, aniżeli znana nam dyscyplina akademicka, zajmująca się badaniem społeczeństw minionych, o których głównym źródłem wiedzy są pozostałości materialne po nich, pozyskiwane na drodze wykopaliskowej” (Mamzer, 2004, s. 196). Podstawowym założeniem H. Mamzera jest teza 
o niemożliwości osiągnięcia bezstronnego, aksjologicznie neutralnego spojrzenia na pradzieje, ponieważ czyste fakty nie istnieją, ,linearny porządek dziejowy, koherencja wydarzeń, przyczynowość czy determinizm okazują się mitami - przekazami światopoglądowymi” (Mamzer, 2003, s. 149), natomiast istnieją zawsze „dla kogoś i dla czegoś", to znaczy, że postrzegana rzeczywistość zawsze jest już zinterpretowana (Mamzer, 1999, s. 196; 2004, s. 33-34). Dzieje się tak, ponieważ archeologia jest zakorzeniona w filozofii dziejów, która stanowi ,próbę odpowiedzi na pytanie o przeszłość, które stawia sobie każda epoka” (Mamzer, 2004, s. 190). Archeologia, jak każda inna nauka, pełni rolę dostarczycielki danych, służących zaledwie potwierdzeniu wcześniej zakładanych tez (Mamzer, Ostoja-Zagórski, 2007, s. 133). Archeologia owa znalazła najpełniejszy wyraz pod postacią „mitu etnicznego”. W sposób szczególnie eksponowany w archeologii problem etniczny to problem jak najbardziej nam współczesny: stanowi realizację postulatów nowożytnoeuropejskiej cywilizacji, interes nauki scjentystycznej i czysto technicznej. W istocie H. Mamzer uczynił ,etniczność" lejtmotywem swej działalności naukowej, w szczególności zajmując się dyskutowanym od przeszło wieku zagadnieniem etnogenezy Słowian w kontekście sporu autochtonistów z allochtonistami (np. Mamzer 1999, 2000b, 2007, 2012a).

Jedną z najsurowszych krytyk na dotychczasowe utożsamianie kultur archeologicznych z etnosami przypuścił Janusz Ostoja-Zagórski, który twierdzi, że dominujące obecnie podejście należy nazywać prezentyzmem, a więc tendencją do patrzenia na przeszłość przez pryzmat teraźniejszości, narzucaniu jej swoistych dla współczesności pojęć i poglądów (Ostoja-Zagórski, 2000, s. 203-204). Archeologowie na podstawie swoich źródeł nie są w stanie odtworzyć prawdziwej rzeczywistości takiej, jaką ona była, ponieważ wszelka wiedza jest społecznie konstruowana: „pozostałości materialne, rozumiane jako swoistego rodzaju «korelaty» nie są i nie mogą być bezpośrednim źródłem, są natomiast fenomenami, którymi uczony manipuluje, by owe źródła stworzyć. [...] Są jedynie jej interpretacjami, z konieczności subiektywnymi i tendencyjnymi" (Ostoja Zagórski, 1996, s. 6). Tak dobitnie stanowisko wyraża również H. Mamzer: „nie jest możliwa uniwersalna obiektywność pradziejów takich, jakimi one w istocie były same w sobie we wszystkich epokach, okresach czy kulturach" (Mamzer, 1997, s. 15). Równie mocno wybrzmiewa zdanie P. Urbańczyka, że „przeszłość nie istnieje” (Urbańczyk, 2000, s. 11). Iluzja obiektywizmu wynika w głównej mierze ze specyfiki źródła archeologicznego, które na pierwszy rzut oka jawi się jako „rzeczywistość miniona [...] spetryfikowana w pozostałościach materialnych" (Mamzer, 1994, s. 16).

Zbyt daleko posunięty w swoich wnioskach konstruktywizm grozi olbrzymią dowolnością formułowanych wniosków. Wśród archeologów polskich zdała sobie z tego sprawę Danuta Minta-Tworzowska, która dostrzegając wady zarówno podejścia kulturowo-historycznego (tradycyjnego), jak i procesualnego, nie umniejsza ich znaczenia w obrębie strategii badawczej nazywanej „krzyżowaniem się paradygmatów”, rozumianego na wzór dekonstrukcji stosowanej przez Iana Hoddera (Hodder, Hutson, 1986, s. 64-65). D. Minta-Tworzowska swoje wnioski formułuje bezpośrednio nawiązując do myśli Jerzego Topolskiego $(1968,1983)$, który widział wielkie szanse 
na rozwój nauk historycznych w integrowaniu badań empirycznych i teoretycznych. Zdaniem poznańskiej archeolog wybór teorii stosowanej przez archeologa nie jest nigdy neutralny aksjologicznie i stanowi środek przeniesienia wartości i pojęć kultury badacza na kulturę badaną, dlatego ważne jest znalezienie odpowiedzi na pytanie, który z paradygmatów najlepiej oddaje daną część rzeczywistości? Już jednak sam fakt, wzmiankowany zresztą w tym samym artykule przez badaczkę, że następujące po sobie teorie, choć ogłaszały opozycyjność w stosunku do poprzedzających je czy też postulowanych równolegle, to jednak koegzystowały, nakładały się na siebie, sprawia, że uzgodnienie linii granicznych kolejnych paradygmatów badawczych nie jest możliwe. Krzyżowanie się paradygmatów w ramach uzgodnionego „podziału zadań” nie unieważnia przecież pretensji kolejnych badaczy do posiadania jedynej i słusznej prawdy w tej czy we wszystkich kwestiach (Minta-Tworzowska, 2000, s. 192-193).

Niniejszy artykuł stanowi przyczynek do krytyki skrajnego konstruktywizmu w badaniu przeszłości. Clue poniższego rozumowania sprowadza się do podstawowego rozróżnienia esencjalizacji etniczności jako zjawiska w istocie zewnętrznego wobec archeologii, narzuconego jej przez rzeczywistość społeczno-historyczną, w której archeologia realizuje się jako praktyka badawcza, od esencjalizacji kategorii heurystycznych, za pomocą których operacjonalizuje się zmienne dostarczane przez praktykę archeologiczną, np. kultury archeologiczne. Przy całej swojej złożoności kategorie te, np. kultury archeologiczne, stanowią quasi-taksony w linneuszowskim słowniku archeologii i jako takie stanowią swoisty przedmiot badawczy archeologii jako odrębnej dziedziny nauki. Takie ujmowanie kategorii heurystycznych archeologii postuluje

przeniesienie rozważań nad pojęciem „kultura” na tę samą płaszczyznę, na której genetyka i demografia, inspirowane przez myśl strukturalistyczną, umieszczają pojęcie izolatu. Według C. Levi-Straussa: „,kulturą zwiemy każdy zespół etnograficzny, a także, jak sądzę archeologiczny, który z punktu widzenia danego badania wykazuje w stosunku do innych istotne odmienności”. (Tabaczyński, 2005, s. 39)

Krytyka esencjalizmu etniczności powinna zostać z istotnych metodologicznych względów oddzielona od krytyki esencjalizmu swoistych dla archeologii kategorii heurystycznych, jakimi są np. kultury archeologiczne. W istocie problem ten wynika z niejednoznaczności archeologii jako nauki, która z jednej strony przynależy do nauk humanistycznych, z drugiej zaś od zawsze rości sobie pretensje do bycia przedstawicielką nauk ścisłych. Wydaje się, że dotychczasowe paradygmatyczne spory w obrębie archeologii wynikają z tej właśnie dwuznaczności statusu przedmiotu badań, którym archeologia się zajmuje. Zwolennicy paradygmatu konstruktywistycznego z całą mocą przekonują, że archeologia jest przede wszystkim nauką humanistyczną.

Metafora archeologii umożliwia archeologom uświadomienie sobie kulturowego uwikłania archeologii jako jednej z dyscyplin naukowych. Pozwala na dekonstrukcję elementów wikłających ją w praktykę społeczno-kulturową, żeby z nimi definitywnie zerwać. Owe elementy wymagające dekonstrukcji i zerwania to wszystkie dogmaty klasycznego myślenia archeologów. Elementy owe konstytuują bowiem ciągłość, 
a myślenie dyskursywne kładzie akcent na istniejące nieciągłości, przeciwstawia się uniwersaliom językowym i ontologicznym. Ciągłość konstytuowana jest zaś przez metahistorię, związki teleologiczne, mit genezy. Archeologia klasyczna, dostarczając opis rzeczywistości pradziejowej według kryteriów zaczerpniętych ze współczesności badacza, buduje swego rodzaju metafizykę obecności. Archeologia jako metafora - wzorem poststrukturalistycznej krytyki metafizyki obecności - wskazuje na subiektywność wszelkiego poznania i niemożność dotarcia do źródłowego sensu, ponieważ ów źródłowy sens, warstwa zerowa według terminologii M. Foucaulta, nie istnieje (Mamzer, 2004, s. 210-211).

Jednocześnie jednak metafora archeologii naraża archeologię na szwank, jeśli pojmuje się ją jako odrębną dziedzinę nauki, posiadającą swoisty przedmiot badań i metody. Przede wszystkim archeologowie powinni być świadomi swoistości swojego przedmiotu badań. Wszelkie próby bezpośredniej aplikacji teorii z innych dziedzin nauki na grunt archeologii w celu wyjaśnienia swoistego dlań przedmiotu muszą zakończyć się fiaskiem (Tabaczyński, 1987, s. 38, przyp. 13). Szczególnie istotne jest zrozumienie różnic między archeologią a historią oraz antropologią kulturową, które często stanowią źródło poznawczych kalek (Tabaczyński, 1987, s. 43-44).

Mimo że w swej praktyce archeologowie obcują z konkretnymi rzeczami - materialnymi korelatami kultury - a ich metoda prowadzić ma do jak najściślejszego oddzielenia skutków działań podepozycyjnych, ażeby dotrzeć do filozoficznie rozumianej rzeczy samej, to za sprawą metafory archeologii cała rzeczywistość materialna podlega tekstualizacji, wszystko jest nieskończonym odnoszeniem się do czegoś innego. W istocie wynika to ze zbyt wąskiego rozumienia terminu „działań podepozycyjnych", ponieważ poza sferą materialnych przekształceń materiału archeologicznego, wymienić wypada całą sferę kulturowych przekształceń, którym materiał ten podlegał, podlega i będzie podlegać w przyszłości. Co prawda, konstruktywiści zakładają, że archeologia powinna zerwać z dotychczasową historyczną perspektywą i szukać ratunku u antropologów, ponieważ uwypuklanie metod właściwych jednej $\mathrm{z}$ tych dwu dyscyplin naukowych bierze się z tej, a nie innej wizji rzeczywistości (Mamzer, 2004, s. 19; Werbart, 2000, s. 151-152; por. również Urbańczyk, 2006; Barford, 2006, s. 126). Jednak wskazując, że nie ma żadnej bezpośredniej relacji między etnosem a kulturą archeologiczną, uznają potrzebę wprzęgnięcia ich w badania dotyczące szerszych i bardziej skomplikowanych struktur, uwzględniających relacje władzy, politykę, związki pokrewieństwa:

zarówno w pradziejach, jak i we wczesnym średniowieczu miały miejsce zarówno zjawiska kohabitacji różnych heterogenicznych grup ludzkich, jak też - jednak z reguły nieudane - próby tworzenia organizmów homogenicznych. W barbarzyńskiej Europie w interesującym nas okresie dziejów nie doszło jednak w żadnej strefie do jedności kulturowej i etnicznej. Dokonywały się jednak mniej lub bardziej udane procesy integracji i dezintegracji ekonomicznej, społecznej, politycznej i kulturowej. W najdawniejszych dziejach barbarzyńskiej Europy powstawały więc i upadały różne wspólnoty. Zjawiskom tym towarzyszyć musiały niewątpliwie procesy etnogenetyczne. (Ostoja-Zagórski, 1996, s. 151) 
Zdaniem konstruktywistów tradycyjnie ujmowane „kultury archeologiczne” to jedynie „byty postulowane”, konstrukty teoretyczne, których przydatność kończy się wraz z analizą porównawczą rozprzestrzeniania się pewnego typu artefaktu w pewnej przestrzeni (Werbart, 2000, s. 156-157). Stąd nacisk, jaki się kładzie na dynamiczny aspekt etniczności, co wymaga jednakowoż rozstrzygających zmian w obrębie traktowania materiałów archeologicznych oraz samej archeologicznej interpretacji:

w okresie wędrówek ludów społeczeństwa definiowały się etnicznie, gdy wymagały tego specyficzne sytuacje i powody, szczególnie polityczne. [...] Aby móc związać się z różnymi ugrupowaniami politycznymi, ludzie definiowali siebie samych jako: Wizygotów, Franków, Wandalów albo Rzymian; z pewnością mogli oni należeć do wielu różnych grup etnicznych. Etniczność wybierana zgodnie z sytuacją nie stwarzała konfliktów politycznych, wprost przeciwnie - była rezultatem konfliktów. (Werbart, 2000, s. 154)

Chociaż wielu badaczy może czuć sprzeciw wobec opinii, że „należymy do jednej tradycji badawczej, której kluczowym pojęciem i problemem jest «kultura archeologiczna»", to niewątpliwie, mimo bardziej (Ostoja Zagórski, 1988, 1989, 1991) lub mniej krytycznych (Tabaczyński, Pleszczyńska, 1974; Tabaczyński, 1976; Kobylińska, Kobyliński, 1981; Tabaczyński, 1987; Minta-Tworzowska, 1994) opracowań dotyczących stanu polskiej archeologii, żadne z dotychczas zaprezentowanych metodologicznych stanowisk alternatywnych nie zaproponowało „własnej aparatury pojęciowej i metod umożliwiających przetwarzanie danych", aby odciąc się od tego, co jest wspólną własnością intelektualną archeologów tradycyjnych, tj. ,podporządkowanych wszak jednemu celowi, aby osadzić odkrywane źródła w schematach chronologii relatywnej" (Mierzwiński, 2000, s. 209-210).

Dokonując podziału na archeologię zorientowaną historycznie oraz archeologię zorientowaną antropologicznie, H. Mamzer wskazuje na rozdział stanowisk względem osi idiografizm - nomotetyzm, wzmiankowany również przez innych badaczy (Kmieciński, 1997, s. 34-36). Należy jednak zauważyć, że historia nie ogranicza się do podejścia idiograficznego, szczególnie zaś w przypadku nurtów modernistycznych w historiografii nacisk kładzie się na podejście generalizujące (Werner, 2009). Jednakże jeśli archeologia powinna iść ręka $\mathrm{w}$ rękę $\mathrm{z}$ antropologią kulturową czy $\mathrm{z}$ filozofią, to nie w poszukiwaniu sposobów, w jakich teraźniejszość wykorzystuje przeszłość dla swoich własnych celów, bo w istocie jest to działanie niemożliwe. Absolutne teraz stanowi tylko i wyłącznie istniejąca ideologia, która w sensie czasowym może mieć z historycznym teraz niewiele wspólnego. Archeologia powinna wykorzystywać dorobek antropologii kulturowej i filozofii, żeby odsłaniać najgłębsze pokłady rzeczy samej, czyli oddzielić skutki działań podepozycyjnych w rozumieniu kulturowych nawarstwień, w szczególności istniejącej ideologii.

W tym tkwi pierwotny sens metafory archeologicznej obecnej u M. Foucaulta i tylko w ten sposób archeologia może obronić się jako odrębna dziedzina wiedzy, nie popadając $\mathrm{w}$ czysta krytykę istniejacej ideologii. W rzeczy samej pierwotny sens metafory archeologicznej i jej niejako zwrotne zastosowanie w dziedzinie archeolo- 
gii stanowią frapujący problem. Paradoksalnie metafora archeologiczna M. Foucaulta w takiej formie, w jakiej realizowana jest przez konstruktywistów, stanowi samobójstwo archeologii jako odrębnej dyscypliny wiedzy, przejście na pozycję pomocników w drużynie krytyków istniejącej ideologii. Bezrefleksyjnie przyjmowana przez archeologów, przyczynia się do śmierci archeologii sensu stricte. Metafora archeologiczna, którą M. Foucault obmyślił, żywiąc podziw do archeologii sensu stricte, żeby postawić ją za wzór innym naukom, w szczególności historii, zaaplikowana na gruncie archeologii przekształca się w swoje przeciwieństwo i staje się trucizną, jak ów derridiański farmakon (Derrida, 1992). W istocie kluczowa jest tu zmiana kierunku ruchu - Foucaltiańska metafora biegnie od rzeczy ku ich interpretacjom, natomiast konstruktywistyczna aplikacja metafory archeologicznej na polu archeologii biegnie z powrotem - od interpretacji ku rzeczom. Jak gdyby starając się poprawić błysk geniuszu, archeologowie nieświadomi swojej wyjściowej przewagi próbują naprawić błąd, którego nie ma. I w ten sposób sami wpadają w zastawione przez siebie sidła tekstualistycznej interpretacji. Co więcej, nie są świadomi paradoksów, jakie po raz kolejny wskrzeszają, żywiąc nadzieję, że w zakładanej perspektywie uda im się otrząsnąć z błędów, które sami wytykają tzw. cywilizacji/nauce nowożytnoeuropejskiej.

\section{DOGMATY CYWILIZACJI/NAUKI NOWOŻYTNOEUROPEJSKIEJ}

H. Mamzer wskazuje, że w dziedzinie archeologii szczególnie znaczące są następujące dogmaty cywilizacji/nauki nowożytnoeuropejskiej:

1) Dogmat o dziejowej roli państwa jako zwieńczenia życia narodu (Mamzer, 1997, s. 30). Państwo stanowi moment kulminacyjny w życiu narodu, moment jego ukonstytuowania na płaszczyźnie politycznej:

dzieje poszczególnych ludów, to dzieje ich dążeń do stworzenia własnej państwowości. Tak oto państwotwórcze tendencje ukierunkowujące dzieje narodów, w gruncie rzeczy owo ukierunkowanie kształtują ex post factum. [...] Wartości należące dziś dla nas współczesnych do wartości najwyższych, np. naród i państwo, imputujemy badanym przez nas społeczeństwom minionym. (Mamzer, 1997, s. 31)

W istocie do tego sprowadza się rola archeologii jako krytyki ideologii, a więc opacznie zrozumiana lekcja metafory archeologicznej M. Foucaulta. Archeologia rozumiana jest $\mathrm{w}$ tej perspektywie jako narzędzie utrwalania tego lub innego mitu etnicznego. Etniczność staje się conditio sine qua non uprawiania archeologii albo inaczej: archeologia stanowi narzędzie w utwierdzaniu tego lub innego mitu etnicznego. Archeologia w pierwszej kolejności służyła poszukiwaniu dowodów na udowodnienie tezy o tubylczości danego etnosu i ciągłości jego historycznego rozwoju na danym terytorium. Tylko tak wprost wyłożone stwierdzenie budzi uzasadnione zastrzeżenia, ponieważ w rzeczy samej ujmuje archeologię w zupełnym oderwaniu od jej metody. Stanowiąc realizację postulatów, M. Foucault na gruncie archeologii jednocześnie 
zrywa z nimi w sposób niedwuznaczny, bo metafora archeologiczna w gruncie rzeczy opierała się na koncepcji archeologicznej metody. Konstruktywistyczna krytyka zamiast odsłaniać rzeczy same spod nawałów kulturowych przekształceń procesu depozycyjnego, skupia się na krytyce istniejacej ideologii $\mathrm{i}$ w tym upatruje swoje zadanie. A jako taka stanowi tylko kolejną ideologiczną manifestację tej samej walki, nieświadomie reprodukując te same lub nieledwie przekształcone kategorie.

W ten sposób należy ocenić analizy Przemysława Urbańczyka, który wskazując na potrzebę wyswobodzenia się z kręgu współczesnego rozumienia wielu pojęć, znajdując $\mathrm{w}$ tym podejściu remedium na rażący aktualizm większości interpretacji historycznych (np. imputowanie modelu homo economicus czy nowożytnoeuropejskiej racjonalności) (Urbańczyk, 2000, s. 18), popada w poważne teoretyczne problemy. Uznając analizy struktur oraz dystrybucji władzy za skuteczne narzędzie badania przeszłych społeczności, również w celu wykrycia w nich pewnych nieregularności, uznaje tę Foucaltowską definicję władzy za uniwersalnie obowiązującą. Krytykowany za determinizm swojej teorii władzy/wiedzy M. Foucault w ostatnich pracach wskazał na jej historyczny wymiar, jednoznacznie wiążąc ją z rozwojem cywilizacji nowożytnoeuropejskiej (Foucault, 2010, 2011). Brak tej spóźnionej refleksji u poznańskiego archeologa powoduje, że czyni on ze swoiście przez siebie pojmowanej koncepcji władzy zmienną niezależną, tłumaczącą rzeczywistość, ale nigdy do końca. Ponadto, zgodnie z koncepcją P. Urbańczyka, jedynie władza stanowi czynnik tłumaczący etniczność. Polityczna funkcja etniczności, pojmowana jako jej decydujący składnik, rodzi wiele problemów. W gruncie rzeczy jako taka etniczność byłaby wolna od jakichkolwiek związków z rzeczywistością, ponieważ w ten sposób każda etniczność - byleby tylko pełniła pewne funkcje polityczne oraz ze względu właśnie na te funkcje istniejąca - byłaby możliwa. W istocie jest to metafizyka liberalizmu transponowana na przeszłość. Doświadczenie wskazuje wszak, że każdy nie może stać się kimkolwiek, toteż etniczność ma pewne naturalne granice, które wyznaczają pulę możliwych do zaistnienia etnicznych tożsamości. Co więcej, zwracanie uwagi na funkcjonalny i instrumentalny charakter etniczności stanowi pogląd europocentryczny, a w przypadku grup etnicznych badanych metodami historycznymi - również archaizm. Jak bowiem w sposób przekonujący dowieść, że kategoria użyteczności (funkcjonalności) stanowi uniwersalne i ponadczasowe kryterium oceny zjawisk w perspektywie społecznej?

Tymczasem więź etniczna - nawet pojmowana na sposób konstruktywistyczny może wynikać z odmiennych przyczyn, realizując pewne osobnicze imponderabilia. Nawet jeśli czynnik polityczny dominuje przy konstruowaniu więzi etnicznej, nie można na tej podstawie wykluczyć możliwej wagi innych czynników. Zdarza się jednak, że etniczność stanowi w pierwszym rzędzie realizację potrzeby bezpieczeństwa ontologicznego, dopiero w drugiej zaś kolejności społecznej wygody. Oba zarzuty postawione teorii P. Urbańczyka w istocie dotyczą granic imputacji kulturowej oraz wynikają z zaadaptowania przezeń teorii Frederika Bartha, będącej przecież tylko wybiórczym wykorzystaniem zdobyczy psychologii społecznej (Kmieciński, 1997, s. $110-111)$. 
2) Teleologizm jako czasoprzestrzenne uporządkowanie oraz pytanie o genezę. Dzieje stanowią linearny ciąg sytuacji powiązanych przyczynowo-skutkowo, w taki sposób, że sytuacja następująca zawsze stanowi wynik sytuacji poprzedzającej. Teleologiczne uporządkowanie, mimo że w potocznym rozumieniu traktowane jest jako relacja fizyczna, również bierze początek w kategoriach nowożytnoeuropejskiej umysłowości (Mamzer, Ostoja-Zagórski, 2007, s. 134). Założenie o realnym (fizycznym) statusie relacji teleologicznych z jednej strony umożliwia totalizację wielości (niezróżnicowaną masę sytuacji historycznych porządkujemy w jeden słuszny sposób), ale z drugiej - tego rodzaju wyjaśnianie zjawisk wymaga odwoływania się do poszukiwania ich genezy, zakłada się więc tu ab initio szczególny mit genezy.

Za nieuzasadnione należy jednak uznać pojmowanie samej idei przeszłości jako zakładającej przyczynowość. Krytyka linearyzmu-teleologizmu stanowi punkt wyjścia wielu postmodernistycznych ujęć historiografii, ale w istocie wymierzona jest przeciwko teleologicznym interpretacjom czy też podporządkowywaniu interpretacji historycznej koncepcji teleologizmu (np. Wrzosek, 2010, s. 42-43). Na gruncie archeologii krytyka teleologizmu-linearyzmu napotyka dodatkową trudność, o której stanowi specyfika archeologicznej metody. Jak można wnioskować ze słów J. Kmiecińskiego, o ile metoda linearyzmu-teleologizmu stosowana jest na etapie wyjaśniania procesów kulturowych, o tyle na etapie rekonstrukcyjnym mamy do czynienia raczej ze stosowaniem prawa Stenosa o funkcjonalnej zależności zmiennych czasowych (Kmieciński, 1997, s. 138). Toteż krytyki H. Mamzera na temat paradygmatu opartego na związkach linearno-teleologicznych nie należy odnosić do stosowania samej metody stratygraficznej, zakładającej przede wszystkim relacyjność, a nie linearyzm-teleologizm. To jest kluczowe spostrzeżenie, ponieważ unaocznia źródłową przewagę archeologii nad innymi naukami humanistycznymi, która doprowadziła w efekcie M. Foucaulta do obmyślenia metafory archeologicznej.

Co więcej, krytyka teleologizmu-linearyzmu nie musi prowadzić do krytyki przeszłości jako tylko i wyłącznie społeczno-kulturowego konstruktu. Z naszego nowożytnoeuropejskiego punktu widzenia trudno wyobrazić sobie jakiś inny sposób organizacji faktów dziejowych niż relacje przyczynowo-skutkowe, jednak nie można stąd wnosić o nieistnieniu przeszłości in toto w sensie intersubiektywnie weryfikowalnego faktu, nawet jeśli nie jest on nam dany wprost, ale podlega rekonstrukcji w praktyce badawczej archeologów i historyków. Przeszłość istnieje jako pewna potencjalność, którą należy dopiero wydobyć. Rację mają konstruktywiści, kiedy twierdzą, że przeszłość jest nieustannie zagrożona przez same nawet interpretacje, że interpretacje mogą współkształtować to, jaką się jawi przeszłość. Jednakże w istocie taka krytyka przeszłości in toto, jako zawsze w pewnej relacji względem teraźniejszości, jako nieposiadającej własnego esencjalnego bytu, nie stanowi wszak zawieszenia jej w nawias faktu społeczno-kulturowego, ale jej uzurpację na wyłączność. Ten problem wynika $\mathrm{z}$ samej istoty skrajnie konstruktywistycznego poglądu na przeszłość i w istocie kłóci się z jego liberalistycznym programem (Mamzer, 2004, s. 57-59).

3) Dogmat determinizmu technologicznego oraz powiązany z nim dogmat racjonalnego podmiotu. Będący podstawą periodyzacji dziejów postęp technologiczny 
wyraża ludzką wiarę w kategorię „użyteczności” kultury; ewolucyjnie uszeregowane materialne realizacje tej wiary stanowią o rozwoju continuum kultury, natomiast każdorazowe pojawienie się uprzednio niewystępującej techniki kojarzone bywa mimowolnie ze zmianą ludności (Mamzer, 2004, s. 24). Z powyższego wynika, że obowiązujący na gruncie archeologii system trzech epok nie stanowi wzorca wywiedzionego $\mathrm{z}$ tak, a nie inaczej uporządkowanego materiału archeologicznego, lecz stanowi aprioryczną konstrukcję umysłu, reifikującą początek jako źródło ludów oraz arche kultury (Mamzer, 2007, s. 30). Specyfika oraz charakter źródła archeologicznego powodują, że dogmat determinizmu technologicznego trwa niewzruszony mimo następującej sukcesji kolejnych paradygmatów, których reprezentanci poddają krytyce pozostałe elementy tradycyjnego podejścia w archeologii (Mamzer, 2000a, s. 545-547, inne opinie np. Kmieciński, 1997, s. 42-43). Z tego powodu należy zauważyć, że wszelkie próby wyjścia poza tę koncepcję powodują wciąż podobne problemy, jak np. koncepcja poręczności $\mathrm{H}$. Mamzera, do której analizy przejdę jednak w dalszej części artykułu.

\section{DEKONSTRUKCJA ZALOŻEŃ ARCHEOLOGII: KRYTYKA PARADYGMATU ETNICZNEGO ARCHEOLOGII KULTUROWO-HISTORYCZNEJ}

W istocie wszystkie te trzy dogmaty stanowią aspekty jednej wizji historiozoficznej - „białej mitologii” według terminu J. Derridy, która zdominowała myślenie nowożytnoeuropejskie: dziejów linearnych uporządkowanych przyczynowo-skutkowo, dążących do doskonałości państwa (Derrida, 1986; Mamzer, 2004, s. 179). Ów eskapistyczny projekt zrywał ze starożytnym modelem ,wiecznego powrotu” również w ten sposób, że pesymistycznemu światopoglądowi (bezradności wobec fatum) przeciwstawiał optymistyczną perspektywę przyszłej szczęśliwości (eschatologia zbawienia) (Mamzer, 2004, s. 179). H. Mamzer przeciwstawia dalej tej wizji sposób myślenia według kryteriów teorii poststrukturalistycznej.

Według poznańskiego archeologa wyróżnione ideały nauki nowożytnoeuropejskiej stanowiły wyraz ekspansywistycznej polityki Europy, instrument realizacji jej kolonialnych zapędów. Postulowany przezeń realizm metafizyczny stanowił więc narzędzie uzyskania „bezpieczeństwa ontologicznego” (Mamzer, 2007, s. 31), w czym H. Mamzer odwołuje się do późnego Heideggera rozumienia poręczności (a w wyniku - instrumentalizacji świata) jako cechy charakterystycznej ludzkiego - w tym nowożytnoeuropejskiego, naukowego rozumienia świata: „nauka nie ma charakteru kontemplacyjnego oglądu rzeczywistości [...], lecz nastawiona jest na użyteczność praktyczną, mającą na celu wyeliminowanie zagrożeń i uczynienie świata bardziej przyjaznym człowiekowi” (Mamzer, 2008, s. 123).

H. Mamzer, interpretując myśl późnego M. Heideggera, odnosi jej wnioski - zasadnie zresztą - do społeczeństw pierwotnych: 
Heideggerowskie bycie w świecie - jestestwo, oznacza pojmowanie świata jako całości: człowieka i świata razem, świata rzeczy znajdujących się pod ręką, inaczej mówiąc: poręcznych, będących do dyspozycji, użytecznych. Kieruje nim instrumentalna intencjonalność, która zdaniem Heideggera ma charakter pierwotny, źródłowy, wręcz archetypowy. [...] Zatem pierwotne bycie w świecie to obcowanie z rzeczami poręcznymi - narzędziami. Istotą owej pierwotności jest ich użyteczność. (Mamzer, 2012b, s. 81)

Szczególne znaczenie w krzewieniu europejskich ideałów miała ideologia ewolucjonistyczna:

kierując się w swoich badaniach założeniami klasycznego ewolucjonizmu antropologicznego, jaki zawiera się chociażby w trójstopniowym podziale na epoki, archeologia eksponuje w ten sposób normy cywilizacji europejskiej jako podstawowy wzorzec dla rozwoju wszystkich pozostałych kultur, według którego powinny się one rozwijać. Tego rodzaju przekonanie o konieczności naśladowania europejskich wzorów kulturowych niejednokrotnie było przyczyną chęci niesienia owej cywilizacji innym, pozaeuropejskim kulturom bez pytania ich o zgodę. (Mamzer, 1997, s. 33)

Jak się zdaje, nie do końca wyjaśniona przez H. Mamzera pozostaje kwestia paradygmatycznej dualności cechującej współczesną archeologię. Z jednej strony H. Mamzer twierdzi, że wszelka archeologia dzisiejsza realizuje ekspansjonistyczną ideologię Europy, z drugiej wskazuje na szczególne znaczenie kategorii etnicznych w archeologii środkowoeuropejskiej (Mamzer, 1999, s. 192). Jak wolno wnioskować, H. Mamzer nieledwie hipostazuje ów istniejący według niego binarny podział, nie zauważając przy tym ponownie, że nie jest to w archeologii, jako dyscyplinie, podział wyczerpujący. Z perspektywy postkolonialnej należałoby wskazać pojawienie się w ostatnich dziesięcioleciach m.in. nurtu indigenious archaeology (w Polsce znanej raczej pod szeroką nazwą ,archeologia postkolonialna", choć mowa tu o wpływie środowisk niegdysiejszego Trzeciego Świata na rozwój dyscypliny, jaką jest archeologia) (por. np. Bruchac i in., 2010; McNiven, 2016; Nicholas, 2010).

Zdecydowanie większość miejsca w swych pracach H. Mamzer poświęca rekonstrukcji procedury archeologów klasycznych (kulturowo-historycznych), opartej na triadzie wartości: realizmu, naturalizmu oraz uniwersalizmu. Realistyczny pogląd archeologów klasycznych oznacza, że „materialne pozostałości po społeczeństwach minionych są obiektywnym, niezależnym od jakiejkolwiek interpretacji źródłem informacji, źródłem samym w sobie”, a zatem ,„pierwotność poznawczą doświadczenia względem teorii” (Mamzer, 2004, s. 47).

Jednak, jak zreferowaliśmy wcześniej pogląd H. Mamzera, bezzałożeniowe poznanie nie jest możliwe (Mamzer, 2004, s. 110-111). Toteż H. Mamzer uznaje za decydujące dla praktyki archeologicznej przekonanie o istotnej roli czasu i przestrzeni w badaniach społeczeństw minionych, jednak w tej jego formie, w jakiej występują w cywilizacji nowożytnoeuropejskiej: „Czas i przestrzeń są w archeologii współrzędnymi stałymi, niezmiennymi, pozostającymi w związku z przekonaniem o obiektyw- 
nym, tzn. niezależnym od nas samych charakterze dziejów adekwatnych do rzeczywistości” (Mamzer, 2004, s. 63).

Podstawowa zasada organizująca myślenie w obrębie tego paradygmatu, wywiedziona z nowożytnoeuropejskiego rozumienia czasu i przestrzeni, głosi, że z podobieństwa dwóch wytworów można wnioskować o ich wspólnym pochodzeniu, tzn. o ich równoczesności oraz o tożsamości ich wytwórców (Mamzer, 2004, s. 66). Czas dla archeologa o nastawieniu kulturowo-historycznym stanowi funkcję podobieństwa wytworów. Kierunek upływu czasu wyznaczony zostaje na podstawie technologicznego zaawansowania oraz złożoności i/lub utylitarnego dostosowania (Mamzer, 2004, s. 81). Tożsamość (identyczność) wytworów = tożsamość (identyczność) wytwórców = ich równoczesność (teraźniejszość). Równoczesność rozumiana jest zaś jako równoczesność wytworzenia oraz równoczesność wyjścia z użycia (identyczność czasu trwania) (Mamzer, 2004, s. 73). Wszelkie dające się zaobserwować różnice dwóch wytworów (inność) zostają wyeliminowane poza obręb rekonstruowanego archeologicznie „teraz”: „Inność wyeliminowana zostaje ze wspólnoty, oznacza to, że nie tylko nie może funkcjonować w jej obrębie [...], lecz również nie może funkcjonować $\mathrm{z}$ nią w tym samym czasie. Może funkcjonować «przed» lub «po», ale nie równocześnie" (Mamzer, 1998, s. 301).

U podstaw wszelkiego archeologicznego myślenia leży więc zabieg redukcjonistyczny (Mamzer, 2004, s. 69). Wnioskowanie to zdaniem H. Mamzera jest wynikiem postawy etnocentrycznej (Mamzer, 1998, s. 302-303), co więcej - przez zredukowanie tożsamości wytwórców do tożsamości ich wytworów dokonujemy wskazania pewnej puli psychofizycznych predyspozycji, których posiadanie stanowi conditio sine qua non powstania tychże wytworów - budujemy więź etniczną według kryteriów rasowych (Mamzer, 2004, s. 117-118).

W istocie krytyka paradygmatu klasycznego według H. Mamzera ma tyczyć się „sprowadzania praktyki badawczej archeologa do «czystego» opisu owego naturalnego (materialnego) stanu rzeczy, z całkowitym pominięciem sytuacji kulturowej, w której było ono usytuowane", co oznacza zasadniczą reorientację archeologii, jeśli chodzi o przedmiot badania $-\mathrm{z}$,przeszłości społecznej” na stricte materialne korelat jej istnienia (Mamzer, 2004, s. 41).

Zdaniem H. Mamzera archeologowie kulturowo-historyczni operują pojęciem zmiany kulturowej, której interpretacja uzależniona jest od rezultatu sposobu postrzegania. Zmiany ewolucyjne, występujące w granicach umożliwiających obserwację, interpretowane są jako „zmiany tej samej ludności”, tzn. zmiany kultury materialnej, bez zmiany czynnika etnicznego. Natomiast gwałtowne i całościowe zmiany, uniemożliwiające obserwację, interpretowane są jako „zmiany spowodowane pojawieniem się ludności innej” (Mamzer, 1999, s. 178-179). W ten sposób zmiana techniczna zostaje zidentyfikowana/utożsamiona ze zmianą etniczną (Mamzer, 2004, s. 82). Paradygmatycznym przykładem posługiwania się tą procedurą jest - zdaniem H. Mamzera - działalność naukowa K. Godłowskiego (Godłowski, 1979, 1985, 1988). Zwróćmy jednak uwagę na to, że H. Mamzer nie przywołuje kluczowej w tych dociekaniach definicji kultury archeologicznej, za po- 
mocą której K. Godłowski wyraźnie odcinał się od imputowanego mu myślowego związku z dziedzictwem G. Kossinny. Krakowski archeolog kulturę archeologiczną definiował bowiem jako:

zbiór charakterystycznych elementów kulturowych uchwytnych w źródłach archeologicznych i współwystępujących ze sobą w powtarzającym się układzie na określonym obszarze i w określonym czasie. Najczęściej chodzi tu o charakterystyczne typy zabytków i uchwytne dla nas elementy zwyczajów pogrzebowych, ale mogą wchodzić też w grę zjawiska z dziedziny gospodarki, znajomości i rozpowszechniania pewnych technik i surowców, budownictwa, form osadnictwa, pojętego w sposób bardziej kompleksowy stroju itp. - o ile tylko rysujące się tu prawidłowości są udokumentowane przez odpowiednią ilość krytycznie zanalizowanych obserwacji archeologicznych”, innymi słowy jest „robocza jednostka pozwalająca na klasyfikację czasowo-przestrzenną materiału archeologicznego, a kryteria tej klasyfikacji są w praktyce różne dla poszczególnych okresów i trenów, przede wszystkim w zależności od bogactwa i stanu zachowania się archeologicznej bazy źródłowej. (Godłowski, 2000, s. 66-67)

Mówiąc o dyskontynuacji, K. Godłowski miał na myśli ,zachodzące w sposób nieewolucyjny zmiany $\mathrm{w}$ istniejącej na danym terenie kulturze archeologicznej, wpływające na jej ogólny obraz i strukturę", które uniemożliwiają stosowanie dla dwóch kultur tej samej nazwy, „nawet jeśli pomiędzy wcześniejszą i późniejsza kulturą rozwijającą się na danym terenie istnieją łączące je elementy" (Godłowski, 2000, s. 67). Sprzeciw K. Godłowskiego wobec metody G. Kossinny znajduje wyraz we wskazaniu, że należy „rozróżniać nie tylko pojęcia ciągłości kulturowej i kontynuacji osadniczej, ale również kontynuacji (w ograniczonym zakresie) osadniczej i tożsamości składu etnicznego mieszkańców danego terenu" (Godłowski, 2000, s. 67).

Zgadzając się zasadniczo co do tezy H. Mamzera, że „to, co bezpośrednio obserwowalne jest zjawiskiem pozornym, nie zaś jego istotą" (Mamzer, 1993, s. 143, przyp. 5; por. Mamzer, 2004, s. 83), nie sposób nie zauważyć, że punktowana przez niego niekonsekwencja w rozumowaniu K. Godłowskiego („,kultura pomorska i grobów kloszowych oraz przeworska i oksywska pomimo radykalnych między nimi różnic są zdaniem K. Godłowskiego wytworem tej samej ludności”, Mamzer, 2000, s. 178-179; por. Godłowski, 2000, s. 69), świadczy jedynie o słabości podanego wyżej podziału zmiany kulturowej. Podział wykoncypowany przez H. Mamzera, który imputuje on dopiero archeologom kulturowo-historycznym jest podziałem idealnotypologicznym, nadto nie jest raczej podziałem wyczerpującym, skoro nie dostrzega on omówionej przez K. Godłowskiego sytuacji.

Rozpatrując H. Mamzera krytykę pojęcia czasu znamionującego klasyczne podejście archeologów, należy zastanowić się nad jego zasadnością z jeszcze jednego punktu widzenia. Czy bowiem sposób postrzegania czasu przez społeczeństwa minione ma wpływ na to, jak czas faktycznie funkcjonował? Jeśli absolutyzujemy poznanie naukowe jako pewny środek poznania rzeczywistości - to nie (błąd naturalistyczny). W świetle przedstawionych przez J. Topolskiego podziałów czasu należy zaznaczyć, że czym innym jest wstępne zrozumienie pojęcia czasu dla przedstawicieli 
społeczności badanej archeologicznie dla pełniejszego jego opisu, czym innym zaś sama krytyka badania dziejów owej społeczności według kryterium czasu nowożytnoeuropejskiego (Mamzer, 2004, s. 87).

Obok przywołanego przez H. Mamzera równania „tożsamość (identyczność) wytworów = tożsamość (identyczność) wytwórców = ich równoczesność" archeologię kulturowo-historyczną ma charakteryzować inne jeszcze założenie, zgodnie z którym „każda wspólnota etniczna charakteryzuje się ściśle określoną kulturą materialną bez względu na epokę (okres czasowy)" (Mamzer, 2000, s. 182; 2004, s. 93 i n.). Słusznie H. Mamzer zauważa, że wzięte wespół te dwa założenia powodują powstanie sprzeczności. Po pierwsze bowiem historyczność (pradziejowość) to zmiana, a

[p]oszukiwanie „tego samego” w możliwie najdalszej przeszłości, to poszukiwanie jego niezmienności, to przekonanie o wiecznym, ponadczasowym trwaniu", wybiegające „wręcz w transcendencję”, to „mityzacja wspólnoty etnicznej” (Mamzer, 1999, s 197), „poszukiwanie ukrytej pod ich [wydarzeń] powierzchnią, niewidocznej „gołym okiem” mitycznej (mimo bowiem zachodzących zmian) niezmienności, swego rodzaju „ducha narodu” na wzór Herderowskiego Volksgeistu. (Mamzer, Ostoja-Zagórski, 2007, s. 136-137)

Kultura nie jest przez archeologów kulturowo-historycznych rozumiana na sposób kulturoznawczy, ale identyfikowana z ludem/wspólnotą etniczną (Mamzer, 2004, s. 97). Z drugiej zaś strony owe momenty identyczności, ponadczasowe wyznaczniki etniczności stanowić mają w praktyce archeologicznej jasne i precyzyjne datowniki dla pozostałego materiału archeologicznego (Mamzer, 2004, s. 185). Trzeci paradoks, który bierze swój początek z łącznego zastosowania obu założeń, prowadzi do sytuacji, w której każda radykalna zmiana kultury materialnej, jakie np. cechują przejścia od jednej do drugiej epoki, byłyby równoznaczne z całkowitą zmianą etniczną (Mamzer, 1999, s. 184).

Dwie pierwsze sprzeczności wynikają z nieporozumienia co do pojęcia „niezmienności", rozumianego w sensie absolutnym przez H. Mamzera, czego nie można powiedzieć o archeologach, którym dopiero H. Mamzer to pojęcie „niezmienności” imputuje. Już choćby stwierdzenie, że praski typ ceramiki jest elementem charakterystycznym dla tej czy innej kultury, odnoszone jest do pewnej sytuacji historycznej, pewnego przedziału czasu, w żadnej mierze nie stanowi o ponadczasowo ujmowanej kulturze Słowian w ogóle.

W ostatnim zaś przypadku warto zauważyć jeszcze, że przestaje on mieć zastosowanie w przypadkach, gdy kolejno wyróżniane epoki archeologiczne traktujemy jako li tylko kategorie heurystyczne, porządkujące dane, na wzór postulowanych kultur archeologicznych. „Konstruktywistyczny” pogląd H. Mamzera zdaje się więc mieć wybiórcze zastosowanie w argumentacji, raz będąc wykorzystanym dla wypunktowania braków w argumentacji przeciwnika, innym zaś razem ustępując pola bardziej „tradycyjnym” - esencjonalizującym argumentom (sic!).

Konstatując paradoksalność tezy o niezmienności, autor nie zauważa, że choć zmiana (ewolucyjna) dotyczy kultury materialnej, a postulowana niezmienność - 
zbiorowości ludzkiej (etnosu) miesza ze sobą oba porządki, aby wypunktować to dopiero swoim przeciwnikom (o ewolucji: Mamzer, 2004, s. 96-97).

Dla odnalezienia owych „momentów identyczności” badacze zwracają się ku problemowi etnogenezy, której punkt wyjścia ma stanowić niczym niezmącone źródło tożsamości wspólnoty etnicznej poprzez dzieje. To szczególny moment w argumentacji H. Mamzera, ponieważ odrzuca on problem etnogenezy jako „po prostu” problem badawczy, wymagający wyjaśnienia, lecz rozumie go raczej jako metodę potwierdzenia etnicznego mitu (Mamzer, 1999, s. 188). Równolegle do poszukiwania ścisłego początku w czasie następuje poszukiwanie ścisłego początku w przestrzeni, stąd wszelkie redukcjonistyczne zabiegi i „budzące wątpliwości wielu badaczy” (Leciejewicz, 1997, s. 167) koncepcje o niewielkim w sensie terytorialnym punkcie wyjścia ekspansji Słowian (Mamzer, 1999, s. 190).

Przeciw „mitowi etnicznemu” przemawia najwymowniej to, że kultura materialna na obszarze zamieszkiwanym przez jakąkolwiek grupę etniczną prezentuje ogromne zróżnicowanie, w szczególności w sferach pogranicznych (Mamzer, 1999, s 187). Postulowana jednolitość tzw. kultury słowiańskiej stanowi idealizujące spojrzenie na rzeczywistość faktyczną, które eliminuje z pola widzenia wszelką inność, która w myśl równania identyczności musi funkcjonować „przed” lub „po”, ale nie równocześnie, bo równoczesność oznacza identyczność i tożsamość wytworów (Mamzer, 1999, s. 187). H. Mamzer przygląda się w szczególności badaniom Michała Parczewskiego, kontynuatora myśli K. Godłowskiego i zarazem jednego z najbardziej zagorzałych obrońców tezy o allochtonizmie Słowian w międzyrzeczu Odry i Wisły (Parczewski 1988a, 1988b, 2002, 2005). Zdaniem poznańskiego archeologa doszukiwanie się przez M. Parczewskiego etnicznej proweniencji takich elementów kultury materialnej, jak ,germańskie” fibule, wschodnioeuropejskie zawieszki trapezowate, „,bałtyjskie” paciorki spiralne z taśmy brązowej, ,,merowińskie” szpile żelazne, ,awarskie” sprzączki i pierścienie, i na koniec „praski” typ ceramiki jako etniczny wyróżnik słowiańskości, to „sięgające absurdu zabiegi redukcjonistyczne” (Mamzer, 1999, s. 189), które prowadzą krakowskiego badacza do śledzenia ekspansji kultury słowiańskiej w kierunku zachodnim znad górnego i środkowego Dniepru na podstawie zmian kąta nachylenia brzegu naczyń (Mamzer, 1999, s. 191; 2004, s. 110). Podobną krytykę wystosowali wobec technicznej procedury M. Parczewskiego - choć czasami nie wymieniając jego imienia, a skupiając się na problemie opierania interpretacji na analizie zespołów praskiej ceramiki - również Lech Leciejewicz (2000, s. 461; 2006, s. 32-33), Florin Curta (2006, s. 51-52) oraz Paul Barford (2006, s. 129). I w tym wypadku, podobnie jak w kontekście krytyki koncepcji K. Godłowskiego, H. Mamzer nie dostrzega całokształtu myśli oponenta, ufundowanej przecież nie na genetycznej definicji kultury, ale na wskroś strukturalistycznej. Nawiązując do twórczości swojego naukowego mentora, M. Parczewski kulturę archeologiczną rozumie jako

rozległa stopniowo rekonstruowana struktura terytorialna, ograniczona przestrzennie (ta przestrzeń mogła w przeszłości poszerzać się lub kurczyć) oraz czasowo, zbudowana z setek i tysięcy powtarzających się, silnie zhierarchizowanych układów reliktów kopalnych, 
od najprostszych po najbardziej złożone, pozostawionych przez kilka lub więcej generacji ludzkich. Wzorce wspomnianych podsystemów cząstkowych ulegały w okresie istnienia wspólnoty kulturowej nieustannym przemianom. Zasięgi geograficzne cech dystynktywnych omawianego fenomenu pokrywają się w znacznym stopniu ze sobą. Kultura archeologiczna mniej lub bardziej dokładnie odzwierciedla różne etapy minionej egzystencji wielkiej zbiorowości ludzkiej, pokrewne sobie cechy wspólnotowe ujawnia w następujących uchwytnych dla archeologa dziedzinach: sposób i zakres korzystania z dóbr środowiska przyrodniczego w tym charakter osadnictwa; formy budownictwa; przejawy aktywności gospodarczej oraz poziom zaawansowania technicznego i technologicznego; standard życiowy populacji, poziom zróżnicowania społecznego; stylistyka i ewentualne walory artystyczne wytworów; kierunki, siła i zasięg kontaktów ze światem zewnętrznym; sztuka wojenna; obrządek pogrzebowy; a niekiedy również wycinkowo inne sfery życia (np. sposób organizacji społecznej, kult religijny). (Parczewski, 2005, s. 66-67)

Schemat postępowania badawczego M. Parczewskiego (2002) wychodzi więc od analizy źródeł pisanych, na podstawie których uznaje, że do połowy VI w. terytorium zamieszkałe przez Słowian „sięgało górnej Wisły, dalej biegła po zewnętrznym łuku Karpat Wschodnich i Południowych, a następnie trzymała się linii dolnego Dunaju. Od delty tej rzeki rubież zmierzała ku wschodowi, na północ od pasma stepów nadczarnomorsko-azowskich, wkraczając daleko na lewobrzeże Dniepru" (Parczewski, 2002, s. 143). Następnie M. Parczewski dokonuje identyfikacji najwcześniejszej słowiańskości poprzez źródła archeologiczne, wskazując na wczesnosłowiański charakter kultury praskiej w części północno-zachodniej tego obszaru oraz kultury Pieńkowka w lasostepie Ukrainy oraz Mołdawii, które łączą takie podstawowe elementy modelu kulturowego, jak: 1) charakter osadnictwa, 2) gospodarka, 3) typ obrządku pogrzebowego oraz 4) brak szerszych kontaktów ze światem zewnętrznym. W kolejnym kroku swej analizy M. Parczewski w obrębie wybranego już obszaru dokonuje oceny, w którym jego fragmencie da się obserwować ,pełna i najbliższa zgodność rozpoznawalnych struktur paleoetnograficznych z odpowiednimi atrybutami nieco młodszych ugrupowań o potwierdzonej metryce wczesnosłowiańskiej”, dochodząc do wniosku, że „pomiędzy końcem IV a połową V w. kultura kijowska płynnie przeistoczyła się w kultury Kołoczyn i Pieńkowka, a ponadto wniosły zasadniczy wkład w powstawanie kultury praskiej" (Parczewski, 2002, s. 143). Stąd miała iść dalsza ekspansja Słowian, owa „eksplozja demograficzna" na cały niemal kontynent europejski. Równolegle dokonywana jest rekonstrukcja chronologii oraz przebiegu zanikania zespołów archeologicznych o hipotetycznej przedsłowiańskiej metryce, skonfrontowana z opisami wędrówek ludów w źródłach pisanych.

Porównując ze sobą argumentację rzeczników tezy o autochtonizmie oraz allochtonizmie, H. Mamzer zauważa, że choć w istocie reprezentują one podobne podejście, „to jednak bardziej konsekwentni w stosowaniu założeń badawczych archeologii historyczno-kulturowej okazują się zwolennicy koncepcji "germańskiej»»" (Mamzer, 1999, s. 195; 2004, s. 117-118). „Niekonsekwencja” rzeczników tezy o autochtonizmie Słowian na ziemiach polskich od najdawniejszych czasów bierze się 
z poczynionej przez J. Kostrzewskiego rekapitulacji poglądu G. Kossinny. Zdaniem H. Mamzera

autochtoniści bowiem, głosząc tubylczość Słowian na ziemiach polskich, a więc tożsamość pod względem etnicznym ludności w okresie wpływów rzymskich i we wczesnym średniowieczu, uznają ich tożsamość kulturową, a więc wyrażają sprzeczność wobec stosowanego przez siebie kryterium podobieństwa wytworów jako kryterium tożsamości. (Mamzer, 2004, s. 92)

Jednocześnie owa „niekonsekwencja” właśnie ma pozytywny skutek - „prowadzi wszak do znacznie pogłębionej refleksji metodologicznej” (Mamzer, 2004, s. 92). Pomijając fakt dyskusyjnego rozbratu Józefa Kostrzewskiego z założeniami metody swego niemieckiego mistrza, należałoby zbadać jeszcze ów nieopisany przecież przez H. Mamzera związek „niekonsekwentnego” w istocie czerpania z metody G. Kossinny z rozwojem ,pogłębionej refleksji metodologicznej” (sic!).

\section{DOGMAT DETERMINIZMU TECHNOLOGICZNEGO I KONCEPCJA PORĘCZNOŚCI HEIDEGGERA}

Zreferowana powyżej krytyka etnicznego paradygmatu archeologii poczyniona przez H. Mamzera znajduje w opinii tegoż autora wsparcie w jego kontrargumentacji przeciwko dogmatowi determinizmu technologicznego, który utożsamia on z koncepcją poręczności późnego Heideggera. Po pierwsze więc kultura materialna nie funkcjonuje autonomicznie względem kultury w ogóle - kultura materialna zawsze jest częścią kultury w ogóle. O ile więc postulowanie zmiany w kulturze w ogóle może znaleźć wyraz w kulturze materialnej, o tyle zmiana kultury materialnej nie musi oznaczać zmiany kultury w ogóle (Mamzer, 2004, s. 25). Po drugie zaś, powołując się na przykład kultury materialnej archaicznej Grecji, H. Mamzer wykazuje, że nowy surowiec, np. żelazo, bywał najpierw wykorzystywany do produkcji przedmiotów symbolizujących prestiż jednostki aniżeli przedmiotów codziennego użytku (H. Mamzer powołuje się również na inne - bardziej archaiczne - przykłady: Mamzer, 2012b, s. 83). Z taką samą sytuacją - zdaniem autora Archeologii i dyskursu - mielibyśmy do czynienia w przypadku barbarzyńskiej Europy. W myśl H. Mamzera produkcja w pierwszym rzędzie stanowi środek komunikacji, a nie przedmiot ewolucji:

chodzi o zmianę mocno już przestarzałego - jak pisze J. Habermas - paradygmatu produkcyjnego na rzecz paradygmatu działania komunikacyjnego. Tym bardziej rzecz dotyczy społeczeństw archaicznych. Mamy tu bowiem do czynienia z klasycznym wręcz przykładem imputowania społeczeństwom z odległej przeszłości naszego nowożytnego świata wartości. (Mamzer, 2008, s. 99)

Albo inaczej: ,zmiana kultury to nie zmiana artefaktów [...] lecz zmiana w sposobach ich użycia" (Mamzer, 2004, s. 25). 
Paradygmat późnego Heidegera stanowi w tej perspektywie imputację społeczeństwom archaicznym poglądu oświeceniowego, tymczasem, jak sądzi H. Mamzer, rezultaty działań społeczności pierwotnych nie były ukierunkowane na racjonalność technologicznej użyteczności (Mamzer, 2012b, s. 83). Społeczeństwa pierwotne cechowała postawa mimetyczna, a nie racjonalność nastawiona na technologiczną użyteczność. Nie fizyczne podobieństwo wytworów, ale podobieństwo ich użycia, tj. wskazujące na prestiż, stymulowało postęp cywilizacyjny:

Naśladujący poprzez sposób użycia przedmiotu użytkowanego przez naśladowanego, stawał się tym samym, co naśladowany, zwłaszcza wtedy, kiedy przedmiot ów komunikował o wyjątkowości jego użytkownika. Tego rodzaju naśladowanie jest równoznaczne $\mathrm{z}$ formą komunikowania. [...] Jednym słowem: wytwarzanie to działanie komunikacyjne. (Mamzer, 2012b, s. 85-86)

W perspektywie tak pomyślanego myślenia społeczeństw archaicznych użyteczność technologiczna była czymś wtórnym, a nie decydującym o rozwoju kultury (Mamzer, 2012b, s. 87). Pomijając samo paradoksalne w tym kontekście użycie terminu „postęp”, który H. Mamzer uważa przecież za anachronizm, jeśli mowa o społeczeństwach pradziejowych, należy się zastanowić, czy faktycznie użyteczność technologiczna, tj. konstatacja faktu, że coś jest bardziej użyteczne niż coś innego, nie stanowiło istotnej składowej mentalności uczestników kultur archaicznych. W gruncie rzeczy trudno orzec, na czym innym ów prestiż miałby polegać, jak nie właśnie na technologicznym zaawansowaniu? Wskazując na zaledwie prestiżowy charakter naśladownictwa wzorców celtyckich, H. Mamzer wywarza tylko otwarte drzwi. W istocie twierdzenie o pierwszeństwie znamion prestiżowych nad utylitarnymi (technologicznymi) miałoby sens w sytuacji powoływania się na sytuację zgoła przeciwną, tj. przydawanie prestiżowego charakteru wzorców pod względem technologicznym regresywnych (casus praskiej ceramiki?). Niewątpliwie nawiązywanie do wzorców celtyckich stanowiło sposób na podniesienie prestiżu, jednak w jaki sposób wytłumaczyć ów prestiż, nie powołując się na kryterium technologiczne? (Mamzer, 2012b, s. 99). Jedynym wytłumaczeniem takiej sytuacji jest waloryzowanie dychotomii swój - obcy, tzn. uznawanie za pozytywne wzorce czerpane z zewnątrz, przy równoczesnym uznawaniu wzorców wewnętrznych za negatywne, bo wsteczne/zaściankowe/zamknięte. Tego typu tłumaczenie każdorazowo wymaga jednak kontekstualnego wytłumaczenia, a powzięte bez niego grozi ponownie anachronizmem i przeniesieniem wartości kultury badającego nad kulturę badaną.

W podobne sprzeczności wikła się H. Mamzer, dyskutując z poglądem późnego Heideggera o poręczności jako cesze charakterystycznej dla gatunku ludzkiego. Powołując się na paradoksalne w tym kontekście koncepcje Émila Durkheima, Marcella Maussa i Luciena Lévy-Bruhla, H. Mamzer wskazuje, że społeczeństwa archaiczne cechowała idea „mistycznej solidarności” czy też partycypacji, zogniskowana w zjawisku magii sympatycznej, 
wyrażającej przekonania społeczeństw archaicznych o istnieniu wspólnej więzi łączącej wszystkie rzeczy [co oznacza] że nie istnieje rozdział między człowiekiem a przyrodą i pomiędzy różnymi rodzajami rzeczy w przyrodzie; ludzie są stopieni z wszystkimi rzeczami w przyrodzie. (Mamzer, 2012b, s. 88)

To synkretyczne myślenie o świecie, w którym nie ma miejsca na rozdział podmiotu działającego od przedmiotu działania wcale nie stoi w sprzeczności z koncepcją poręczności Martina Heideggera. W istocie rzeczy poręczne byłyby raczej wyjęte z tego porządku magicznego myślenia, w którym człowiek czuł się częścią przyrody. Myślenie w kategoriach poręczności według M. Heideggera wkrada się niepostrzeżenie w świat kultury magicznej w ten sposób, że to, co naturalne, poddawane przeróbce człowieka, staje się poręczne. Idealizacyjne pojęcie kultury magicznej powinno więc wypowiadać się raczej o rzeczywistości, w której człowiek czuje się częścią przyrody, która nie została poddana jego wpływowi. W rzeczy samej wnioskowanie H. Mamzera sprawia wrażenie, jak gdyby autor imputował społeczeństwom archaicznym nieznajomość rozróżnienia pomiędzy naturalnym a przetworzonym przez człowieka, później zidentyfikowanym jako kulturowe. Błąd w rozumowaniu H. Mamzera bierze się z jego przeciwstawienia kultury magicznej kulturze poręczności, ponieważ podczas gdy poręczność stanowi jedynie instrument $\mathrm{w}$ celu ustanowienia idealizacyjnej kultury poręczności - nigdy jeszcze w sensie absolutnym niezrealizowanej - idealizacyjnej kulturze magicznej, będącej raz na zawsze zaprzepaszczonym dziedzictwem. Wnioskowanie to zdradza więc idealizujące pojmowanie kultury magicznej rozumianej w przeciwstawieniu do idealizacyjnie pojmowanej kultury poręczności. Nie sposób nie zauważyć, że krytykowany przez H. Mamzera determinizm technologiczny ustępuję tu miejsca swego rodzaju determinizmowi etycznemu, przebiegającemu od stadium „magiczne” do „poręczne”.

Europocentryczne nastawienie archeologii nie wynika ze specyfiki europejskiego doświadczenia, tzn. do pomyślenia są wszelkie inne rodzaje etnocentryzmów. Etnocentryzm stanowi naturalną postawę grup społecznych, a „ekspansja kulturowa” stanowi jej naturalną konsekwencję (Mamzer, 2004, s. 218). Tak samo jak jest on naturalny, tak samo jest i niezbywalny - etnocentrycznej postawy nie sposób wyeliminować również z praktyk badawczej archeologa, w czym H. Mamzer upatruje błąd teorii I. Hoddera (Hodder, 1995, s. 184; Mamzer, 2004, s. 222, 225). Jedynym, co można zrozumieć, to wznieść się na poziom „etnocentryzmu oświeconego” czy też ,anty-antyetnocentrymu”, czyli uznania etnocentryzmu za niezbywalny warunek poznania innych kultur. Świadomość własnego etnocentryzmu otwiera bowiem możliwości dialogu:

możliwość partnerskiego dialogu pojawia się wówczas, kiedy uświadomimy sobie fakt, że oprócz nas są również inni, którzy o sobie samych myślą podobnie jak i my. Inaczej mówiąc, możliwość taka zachodzi wówczas, kiedy stajemy się wyrazicielem pluralizmu wartości kulturowych. (Mamzer, 2004, s. 227)

Rozumieć przez to należy przede wszystkim zrozumienie historycznego wymiaru teraźniejszości: „tym, co historycznie samo w sobie jest pierwsze, jest nasza «teraź- 
niejszość»” (Mamzer, 2004, s. 229). Zarówno pozycja „my”, jak i „oni” jest relatywna - w obu przypadkach przyjdą bowiem następni.

Antyetnocentryzm to pluralizm wartości kulturowych, tj. dostrzeżenie, że wartości innych kultur nie stanowią odchylenia czy też dewiacji od wartości „kultury normalnej”; relatywizm kulturowy - „wielość i różnorodność kultur funkcjonujących obok siebie jako zamknięte monady - przeszłość niezależna od «interesów» teraźniejszości" - przeszłość nie jest wytwarzana przez teraźniejszość (Mamzer, 2004, s. 223, 225); ale każde pokolenie pisze swoje pradzieje, ponieważ „historia przeszłości jest zmienna, stale na owo tworzona w miarę powstawania nowej teraźniejszości z jej projektującym perspektywicznie ukierunkowaniem" (Mamzer, 2004, s. 225, 227).

Ale niemożliwe jest prowadzenie dialogu z przeszłością, pojmując ją na sposób naturalistyczny. Oznacza to, że widzenie przeszłości jako procesu prowadzącego do teraźniejszości zawsze prowadzi do uznania teraźniejszości jako pozycji uprzywilejowanej. Jedynie odwrócenie tego porządku, uznanie że teraźniejszość jest historycznie pierwsza, że to z jej punktu projektowana jest przeszłość, umożliwia dialog:

Każde pokolenie - wbrew opinii I. Hoddera - oddziałuje w ten sposób zwrotnie na pradzieje, wskutek czego są one czymś nieskończonym, otwartym i wiecznie odnawiającym się. W takiej oto sytuacji pojawia się możliwość „dialogu z danymi”, dialogu teraźniejszości ze świadectwami przeszłości. (Mamzer, 2004, s. 230)

Szczególna rola w owym dialogu przypada tym danym, których teraźniejszość nie jest $\mathrm{w}$ stanie przewidzieć:

które pozostają w związku z teraźniejszością inną od tej, w której sami jesteśmy usytuowani [...] będącymi świadectwem istnienia rzeczywistości minionej, innej od tej, która stanowi pochodną rzutowanego przez nas w przeszłość perspektywicznego ukierunkowania naszej aktualnej rzeczywistości. (Mamzer, 2004, s. 230)

Nie da się zaprzeczyć, że H. Mamzer problem źródła (archeologicznego) przedkłada ponad inne. To właśnie specyfika źródła oraz jego rozumienie stanowią o istocie dyscypliny naukowej, jaką jest archeologia. To właśnie różne spojrzenie na źródło bądź z perspektywy historycznej bądź antropologicznej - ukierunkowuje analizę (Mamzer, 2004, s. 18-21). W rzeczy samej podejście archeologii kulturowo-historycznej zrekonstruowane przez $\mathrm{H}$. Mamzera uniwersalizuje pojęcie niezmienności jako ponadczasowej tożsamości, czegoś, co jest stale obecne $\mathrm{w}$ dziejach lub też H. Mamzer uniwersalizuje je, nie dostrzegając, że w podejściu archeologii kulturowo-historycznej kryją się inne możliwości rozumienia „niezmienności”. Na początku należy ustalić, do czego można sprowadzić poszukiwanie podobieństw między wytworami (ich niezmienności):

1) poszukiwanie podobieństw między wytworami, które dzieli znaczna perspektywa czasowa (wiele pokoleń) - w przypadku odkrycia niezmienności byłaby to niezmienność pozorna (podobieństwo pozorne), w przypadku odkrycia zaś braku niezmienności - różnicy, mówimy o różnicy całkowitej (absolutnej), 
2) poszukiwanie podobieństw między wytworami, które stanowią dwa kolejno następujące po sobie stadia systemu (przemiany pokoleniowe), które cechuje krótsza perspektywa czasowa, najprawdopodobniej przekroczenie progu w tym wypadku mamy do czynienia z niezmiennością okresową - podobieństwem właściwym - i w tym wypadku można by domniemywać wspólnoty pochodzenia (czynnika etnicznego).

Relatywna ciągłość, o której mowa w przypadku 2 stanowi punkt wyjścia rozważań etnogenetycznych, lecz rozważania te w żadnej mierze nie muszą się do niej ograniczać. Pytanie bowiem, które należy sobie jeszcze postawić brzmi: czy jest możliwe, że dwa zupełnie odmienne wytwory są elementami tego samego procesu rozwojowego? Innymi słowy, czy można wytłumaczyć w zgodzie z modelami ewolucjonistycznymi radykalne nieciągłości inaczej niż za pośrednictwem modelu migracji (dyfuzji)? Zastrzeżmy na początku, że ewolucji kulturowej nie identyfikujemy jeden do jednego z ewolucją biologiczną, zauważając, że rządzi się ona swoimi własnymi prawami i modelami.

Wydaje się, że na tak postawione pytanie należy odpowiedzieć twierdząco: tak, można wytłumaczyć radykalną nieciągłość i pogodzić ją z modelami ewolucjonistycznymi, nie posługując się modelem migracji (dyfuzji), zakładając, że system kulturowy ewoluuje do momentu przesilenia, gdy samopodobieństwo ustępuje różnicy. Być może, w odróżnieniu od biologicznej ewolucji, która zawsze ma w jakiejś mierze charakter kumulatywny (stałość genomu), kulturowe ciągi (r)ewolucyjne nie są procesami o charakterze kumulatywnym, lecz rządzą nimi ciągłe transformacje, mutacje i konfiguracje.

Do niedawna archeologia i nauki historyczne posługiwały się na wskroś ewolucjonistycznym założeniem, zgodnie z którym - ogólnie rzecz biorąc - to, co proste zawsze wyprzedzało w czasie nadejście tego, co złożone. Błędne utożsamienie procesu historycznego z procesem ewolucji biologicznej brało się zapewne z tego, że na początku XX w. uczeni nie posługiwali się jeszcze pojęciami atrybutywnego oraz dystrybutywnego ujęcia kultury. Właśnie za ich pomocą Stanisław Tabaczyński wskazuje, że wprawdzie ,szeroko, atrybutywnie pojmowane kultury przeżywają zawsze jako odwzorowane transmutacje stanów poprzednich. Kultura ludzka jest ciągłością. Będzie trwała zawsze dłużej niż aktualni jej nosiciele” (Tabaczyński, 1976, s. 366), to jednak badając konkretne społeczeństwa ludzkie - mając do czynienia z kulturą w rozumieniu dystrybutywnym - doświadczamy nieustannie braku ciągłości:

topór nigdy nie rodzi innego topora; między dwoma identycznymi narzędziami lub między dwoma różnymi narzędziami o kształtach dowolnie zbliżonych jest i zawsze pozostanie radykalna nieciągłość, która bierze się z faktu, że drugie z nich nie pochodzi od pierwszego, lecz każde wywodzi się z pewnego systemu przedstawień. (Levi-Strauss, za: Tabaczyński, 2005, s. 42)

Kultura ma być więc (ponownie!) bytem paradoksalnym, z jednej strony odznaczającym się ciągłością, z drugiej nieciągłością. Zapytać wypada czy paradoksalność 
tego kalibru, z jakim mamy tu do czynienia, nie wywołuje potrzeby próby sprowadzenia tych dwu ujęć kultury (atrybutywnej i dystrybutywnej) do różnych bytów, aby co najmniej przeciwdziałać terminologicznemu zamętowi.

Ciągłość w istocie wg S. Tabaczyńskiego nie jest zależna od stanu rozpoznania obszaru (np. najlepiej zbadane obszary dzisiejszych Niemiec nie dają możliwości przyjęcia tezy o ciągłości kulturowej, Tabaczyński, 2000, s. 366), ale raczej od przyjętego (nie)świadomie zakresu pojęcia kultury, tzn. czy rozumie się przez nią wszystkie globalnie sfery działalności człowieka, czy tylko wybrane pod kątem ich swoistości. Enumeratywnemu wyliczaniu składników kultury przeciwstawia się właśnie całościowa, semiotyczna i relacyjna koncepcja S. Tabaczyńskiego.

Pojęcie nieciągłości ujawnia się w archeologii w różnej postaci i w zależności od tego, w jakim kontekście występuje, innego znaczenia nabiera. Co istotne: „używane jest jako jedno z podstawowych kryteriów wyróżniających zarówno najmniejsze, jak i najwyższego rzędu układy wchodzące w zakres analizy" (Tabaczyński, 1984, s. 18). Na płaszczyźnie źródłotwórczej S. Tabaczyński mówi o lukach sedymentacyjnych, które przyrównuje do pojęcia diastemów w geologii, definiując je jako:

występujące notorycznie dyskontynuacje umożliwiające podział uwarstwień na konstytuujące je jednostki stratygraficzne o założonym przez badanie stopniu wewnętrznej jednorodności, jako takie będące cechą wspólną budowy układów stratyfikacyjnych, normalnym składnikiem sekwencji warstwowych (obok znacznego zróżnicowania facjalnego, tj. „,współwystępowania w poziomie obocznych odmian poszczególnych warstw”). (Tabaczyński, 1984, s. 9)

Zauważmy, że sam proces stratyfikacyjny charakteryzuje się ciągłością w czasie, nieciągłe jest dopiero jego odwzorowanie, czyli „kopalne przekazy tego przebiegu w postaci uwarstwień”. Nieciągłość tę S. Tabaczyński nazywa jednak „relatywną”, ponieważ każdorazowo obserwowana jest z punktu widzenia jednostki, czyli konkretnego badacza, mającego do czynienia z zaburzeniem ciągłego procesu stratyfikacyjnego, głównie pod wpływem czynników podepozycyjnych. Tak pojęte luki sedymentacyjne (diastemy) stanowią przeszkodę, z którą należy sobie poradzić, np. poprzez obserwacje profili innych wykopów w obrębie stanowiska, osady lub ekumeny osadniczej (Tabaczyński, 1984, s. 10-12).

Innego znaczenia nabiera zjawisko nieciągłości, jeśli rozważamy je w kontekście procesu społeczno-historycznego, a więc rzeczywistości pradziejowej, która stanowi ostateczny cel badania archeologicznego. W tym kontekście stanowią w istocie taki sam przedmiot interpretacji, jak zjawiska obserwowanej ciągłości:

Wyodrębnianie dowolnego układu opiera się bowiem na poszukiwaniu z jednej strony cech zapewniających mu pożądany stopień wewnętrznej spoistości; z drugiej zaś - zespołu istotnych nieciągłości określających stopień odrębności układu oraz jego miejsce w kontekście szerszych procesów. (Tabaczyński, 1984, s. 14)

Co najważniejsze jednak, nieciągłość stanowi nieuświadamianą kategorię porządkującą poznanie, tak jak kantowskie kategorie czasu i przestrzeni, z którymi w isto- 
cie jest powiązana. Przystępując bowiem do badania, „wycinamy” pewien fragment rzeczywistości, czyniąc zeń przedmiot badania. Podstawowe pytanie brzmi więc: na ile to uprzednie względem badania „wycięcie” przedmiotu z ciągłości rzeczywistości zostaje uświadomione sobie przez badacza i uwzględnione przy wyciąganiu wniosków z analizy? Czyli, na ile badanie stanowi jedynie potwierdzenie tego, co było już założone wcześniej, a na ile założenia te poddaje krytyce?

W kontekście nieciągłości procesu społeczno-kulturowego należy odczytywać przywoływane przez S. Tabaczyńskiego słowa M. Foucaulta, według którego nieciągłość przestała być przeszkodą, którą , analiza badacza miała obejść, zredukować, wygładzić, ażeby się ujawniła tych zdarzeń ciągłość" (Foucault, 1977, s. 33), stając się ,jednym z podstawowych elementów analizy” (Foucault, 1977, s. 33): ,jest zarazem instrumentem i przedmiotem badań; gdyż zakreśla pole, z którego jednocześnie wynika; gdyż pozwala wyodrębnić dziedziny analizy, będąc jednocześnie czymś, co ujawnia się, gdy je porównać”; „elementem pozytywnym, który określa ich [badań historycznych] przedmiot i uprawomocnia analizy" (za: Tabaczyński, 1984, s. 8). Z przedstawionej powyżej analizy konstruktywistycznej teorii H. Mamzera wynika, że nie jest $\mathrm{w}$ stanie ona zerwać z żadną z nieciągłości, którymi charakteryzuje tak zwaną i krytykowaną przez siebie archeologię kulturowo-historyczną. Wręcz przeciwnie, starając się wykroczyć poza nie, generuje identyczne problemy, przynajmniej z punktu widzenia własnych etycznych lub metodologicznych założeń. Czy należy to uznać za zwycięstwo paradygmatów klasycznych? Z pewnością nie. A może za nadejście impasu teoretycznego? Bynajmniej. Konstruktywizm w archeologii z pewnością niesie szereg pozytywnych spostrzeżeń, chociażby tezę o uwikłaniu badacza w poznanie, obok których nie można przejść obojętnie bądź bezrefleksyjnie. Z pewnością należy powrócić do Foucultiańskiej metafory archeologicznej i jeszcze raz, ale tym razem poprawnie zrozumieć ją na gruncie archeologii.

\section{BIBLIOGRAFIA}

Barford, P.

2006 Wiedzieć niewiadome. Jak możemy uprawiać archeologię rozprzestrzeniania się języków słowiańskich? W: P. Urbańczyk (red.), Nie-Stowianie o poczatkach Stowian (s. 89-131). Warszawa: Poznańskie Towarzystwo Przyjaciół Nauk.

Bruchac, M., Hart, S. M., Wobst, H. M. (red.)

2010 Indigenous archaeologies: A reader on decolonization. Walnut Creek, CA: Left Coast Press.

Curta, F.

2006 Tworzenie Słowian. W: P. Urbańczyk (red.), Nie-Stowianie o początkach Stowian (s. 2755). Warszawa: Poznańskie Towarzystwo Przyjaciół Nauk.

Derrida, J.

1986 Biała mitologia. Metafora w tekście filozoficznym (W. Krzemień, thum.). Pamiętnik Literacki, 77(3), 283-318.

1993 Farmakon. (B. Banasiak, thum.). W: J. Derrida, Pismo filozofii (s. 39-61). Kraków: inter esse. 
Foucault, M.

1977 Archeologia wiedzy. Przeł. A. Siemek. Warszawa: Państwowy Instytut Wydawniczy.

2002 Porzadek dyskursu. Wykład inauguracyjny wygtoszony w Collège de France 2 grudnia 1970 (M. Kozlowski, tłum.). Gdańsk: Wydawnictwo słowo/obraz terytoria.

2010 Bezpieczeństwo, terytorium, populacja (M. Herer, thum.). Warszawa: Wydawnictwo Naukowe PWN.

2011 Narodziny biopolityki (M. Herer, thum.). Warszawa: Wydawnictwo Naukowe PWN.

Godłowski, K.

1979 Z badań nad zagadnieniem rozprzestrzeniania Stowian w V-VII w. n.e. Kraków: Akademia Górniczo-Hutnicza im. S. Staszica.

1985 Przemiany kulturowe i osadnicze w poludniowej $i$ środkowej Polsce w młodszym okresie przedrzymskim $i$ w okresie rzymskim. Wrocław: Ossolineum.

1988 Problemy chronologii okresu rzymskiego. W: M. Gedl, R. Jamka (red.), Scripta Archaeologica (s. 27-47). Kraków: Państwowe Wydawnictwo Naukowe.

2000 Zagadnienie ciągłości kulturowej i kontynuacji osadniczej na ziemiach polskich w młodszym okresie przedrzymskim, okresie wpływów rzymskich i wędrówek ludów. W: K. Godłowski, Pierwotne siedziby Stowian (s. 66-95). Kraków: Instytut Archeologii Uniwersytetu Jagiellońskiego.

Hodder, I.

1995 Interpreting Archaeology. Finding meaning in the past. London - New York: Rutledge.

Hodder, I., Hutson, S.

1986 Reading the Past. Current approaches to interpretation in archaeology. Cambridge: Cam-

Kmieciński, J. bridge University Press.

1997 Rekonstrukcja minionych kultur. Lublin: Wydawnictwo Uniwersytetu Marii Curie-Skłodowskiej.

Kobylińska, U., Kobyliński, Z.

1981 Kierunki etnoarcheologicznego badania ceramiki: przegląd problematyki. Kwartalnik Historii Kultury Materialnej, 29, 43-53.

Leciejewicz, L.

1997 Z nowszych badań nad pochodzeniem Słowian. W: M. Głosek (red.), Archeologia i starożytnicy. Studia dedykowane Profesorowi Andrzejowi Abramowiczowi w 70 rocznice urodzin (s. 43-67). Warszawa: Instytut Archeologii i Etnologii PAN.

2000 Kultury archeologiczne wczesnośredniowiecznej Europy Środkowej a rzeczywistość etniczna i społeczno-polityczna. W: S. Tabaczyński (red.). Kultury archeologiczne a rzeczywistość dziejowa (s. 101-112). Warszawa: Wydawnictwo Naukowe PWN.

2006 O modelu kultury wczesnosłowiańskiej. W: M. Rębkowski, S. Moździoch (red.), Opera selecta. Z dziejów kultury średniowiecznej Polski i Europy (s. 31-37). Wrocław Warszawa: Instytut Archeologii i Etnologii PAN.

Łowmiański, $\mathrm{H}$.

1964 Początki Polski. Z dziejów Stowian w I tysiącleciu n.e., t. 1. Warszawa: Państwowe Wydawnictwo Naukowe.

Mamzer, $\mathrm{H}$.

1993 Przeciwko dogmatowi determinizmu technologicznego. Archeologia Polski, 38(1), 136150.

1997 Pytanie o archeologię. W: J. Ostoja-Zagórski (red.), Jakiej archeologii potrzebuje wspótczesna humanistyka? (s. 13-49). Poznań: Instytut Historii UAM.

1998 Archeologia jako uobecnianie przeszłości. W: W. Wrzosek (red.), Świat historii (s. 299307). Poznań: Instytut Historii UAM.

1999 Problem etniczny w archeologii, Slavia Antiqua, 40, 169-201. 
2000a Kulturowe konteksty paradygmatów w archeologii. W: M. Kobusiewicz, S. Kurnatowski (red.), Archeologia i prahistoria w ostatnim pótwieczu (s. 537-550). Poznań: Poznańskie Towarzystwo Przyjaciół Nauk.

2000b Mit etniczny w archeologii. W: H. Van den Boom, A. P. Kowalski, M. Kwapiński (red.), Eidolon. Kultura archaiczna w zwierciadle wyobrażeń, słów i rzeczy (s. 99-106). Gdańsk: Muzeum Archeologiczne w Gdańsku.

2003 Strategie konstruktywistyczne w archeologii. W: A. Pałubicka, A. P. Kowalski (red.), Konstruktywizm w humanistyce (s. 149-162). Bydgoszcz: Oficyna Wydawnicza Epigram.

2004 Archeologia $i$ dyskurs. Rozważania metaarcheologiczne. Poznań: Instytut Archeologii i Etnologii PAN

2007 Eskapizm dziejowy. Polityka historyczna a problem bezpieczeństwa wspólnotowego. W: A. Dobosz, A. P. Kowalski (red.), Bezpieczeństwo ontologiczne (s. 17-38). Bydgoszcz: Oficyna Wydawnicza Epigram.

2008 Wytwarzanie w społeczeństwach archaicznych jako działanie komunikacyjne. W: A. Pałubicka, G. A. Dominiak (red.), Język i przedstawienie (s. 98-127). Bydgoszcz: Oficyna Wydawnicza Egigram.

2012a Etniczność. W: S. Tabaczyński, A. Marciniak, D. Cyngot, A. Zalewska (red.), Przeszłość społeczna. Próba konceptualizacji (s. 627-634). Poznań: Wydawnictwo Poznańskie.

2012b Unifikacja kulturowa i hybrydyzacja w społeczeństwach archaicznych. W: B. Gediga, A. Grossman, W. Piotrowski (red.), Rytm przemian kulturowych w pradziejach i średniowieczu (s. 75-108). Biskupin - Wrocław: Muzeum Archeologiczne w Biskupinie, PAN Oddział we Wrocławiu.

Mamzer, H., Ostoja-Zagórski, J.

2007 Orientacje badawcze w polskiej archeologii. Nauka, 1, 131-148.

McNiven, I.

2016 Theoretical challenges of indigenous archaeology: Setting an agenda. American Antiquity, $81(1), 27-41$.

Mierzwiński, A.

2000 Zagadnienie obronności osiedli typu biskupińskiego. O potrzebie alternatywnej interpretacji. Przegląd Archeologiczny, 48, 141-151.

Minta-Tworzowska, D.

1994 Klasyfikacja $w$ archeologii jako sposób wyrażania badań, hipotez oraz teorii archeologicznych. Poznań: Wydawnictwo Naukowe Uniwersytetu im. Adama Mickiewicza.

2000 Archeologiczne rekonstrukcje świata pradziejowego wobec krytyki postmodernistycznej. W: S. Tabaczyński (red.), Kultury archeologiczne a rzeczywistość dziejowa (s. 185-198). Warszawa: Wydawnictwo Naukowe PWN.

Nicholas, G. P. (red.).

2010 Being and becoming indigenous archaeologists. Walnut Creek, CA: Left Coast Press. Ostoja-Zagórski, J.

1988 Empiria i teoria w badaniach archeologicznych. Archeologia Polski, 33(2), 247-269.

1989 Refleksje na temat roli czasu i przestrzeni w badaniach archeologicznych. Kwartalnik Historii Kultury Materialnej, 37, 163-173.

1991 Problemy organizacji halsztackich wspólnot terytorialno-gospodarczych typu biskupińskiego. W: J. Jaskanis (red.), Prahistoryczny gród w Biskupinie. Problematyka osiedli obronnych na początku epoki żelaza (s. 37-56). Warszawa: Państwowe Muzeum Archeologiczne w Warszawie.

1996 Najstarsze dzieje ziem polskich. Bydgoszcz: Wydawnictwo Uczelniane WSP.

2000 Kultury archeologiczne w świetle konstruktywistycznego modelu poznania. W: S. Tabaczyński (red.), Kultury archeologiczne a rzeczywistość dziejowa (s. 199-206). Warszawa: Wydawnictwo Naukowe PWN. 
Parczewski, M.

1988a Początki kultury wczesnostowiańskiej w Polsce. Krytyka i datowanie źródet wczesnośredniowiecznych. Kraków: Ossolineum.

1988b Najstarsza faza kultury wczesnostowiańskiej w Polsce. Kraków: Wydawnictwo Uniwersytetu Jagiellońskiego.

2002 Praojczyzna Słowian w ujęciu źródłoznawczym. W: A. Kokowski (red.), Cień Światowita czyli pięć głosów w sprawie etnogenezy Stowian (s. 23-68). Lublin: Wydawnictwo Uniwersytetu Marii Curie-Skłodowskiej.

2005 Podstawy lokalizacji pierwotnych siedzib Słowian. W: P. Kaczanowski, M. Parczewski (red.), Archeologia o początkach Stowian (s. 65-78). Kraków: Wydawnictwo Uniwersytetu Jagiellońskiego.

Tabaczyński, S.

1976 Kultura i kultury w problematyce badań archeologicznych. Archeologia Polski, 21(2), 365-374.

1984 Zjawisko nieciągłości jako przedmiot analizy archeologicznej. Folia Praehistorica Posnaniensia, 1, 7-21.

1987 Archeologia średniowieczna. Problemy. Metody. Źródła. Cele badawcze. Wrocław - Warszawa - Kraków - Gdańsk - Łódź: Ossolineum.

2000 Kultura archeologiczna w perspektywie przyszłych badań. W: S. Tabaczyński (red.), Kultury archeologiczne a rzeczywistość dziejowa (s. 259-263). Warszawa: Państwowe Wydawnictwo Naukowe.

2005 Procesy etnogenetyczne jako problem badawczy archeologii. W: P. Kaczanowski, M. Parczewski (red.), Archeologia o początkach Stowian (s. 37-50). Kraków: Wydawnictwo Uniwersytetu Jagiellońskiego.

Tabaczyński, S., Pleszczyńska, E.

1974 O teoretycznych podstawach archeologii (prezentacja i próba analizy poglądów D. L. Clarke'a), Archeologia Polski, 19, 7-94.

Topolski J.

1968 Metodologia historii. Warszawa: Państwowe Wydawnictwo Naukowe.

1983 Teoria wiedzy historycznej. Poznań: Wydawnictwo Poznańskie.

Urbańczyk, P.

2000 Władza i polityka we wczesnym średniowieczu. Wrocław: Wydawnictwo Uniwersytetu Wrocławskiego.

2006 Polska archeologia wczesnego średniowiecza a antropologia kulturowa. W: W. Chudziak, S. Moździoch (red.), Stan i potrzeby badań nad wczesnym średniowieczem w Polsce - 15 lat później (s. 31-40). Toruń: Wydawnictwo Uniwersytetu Mikołaja Kopernika w Toruniu.

Werbart, B.

2000 Kultura archeologiczna a tożsamość kulturowa - problemy synchronizacji. W: A. Buko, P. Urbańczyk (red.), Archeologia w teorii i praktyce (s. 147-166). Warszawa: Komitet Nauk Pra- i Protohistorycznych Wydziału I Nauk Społecznych PAN, Instytut Archeologii i Etnologii PAN.

Werner, W.

2009 Historyczność kultury: w poszukiwaniu myślowego fundamentu wspótczesnej historiografii. Poznań: Wydawnictwo Naukowe UAM.

Wrzosek, W.

2010 Historia - kultura - metafora. Powstanie nieklasycznej historiografii. Wrocław: Fundacja na Rzecz Nauki Polskiej. 


\title{
DISCOURSE OF ARCHAEOLOGY ACCORDING TO HENRYK MAMZER: LIMITATIONS OF CONSTRUCTIVIST ORIENTATION AND THE ETHNIC MYTH IN ARCHAEOLOGY
}

\author{
Sum mary
}

By using the concept of "discourse" H. Mamzer attempts to reformulate the research goals of archaeology as a humanistic discipline. The starting point for his considerations in this respect is to draw attention to the "archaeological metaphor" by M. Foucault. Archaeological metaphor "means something more than the academic discipline known to us, dealing with the study of past societies, whose main source of knowledge are material remains of them, obtained through excavation" (Mamzer, 2004, p. 196). H. Mamzer's basic assumption is the thesis of the impossibility of achieving an impartial, axiologically neutral view of prehistory, because pure facts do not exist, "linear historical order, coherence of events, causality or determinism turn out to be myths - ideological messages" (Mamzer, 2003, p. 149), they always exist "for someone and for something", which means that reality is always being interpreted (Mamzer, 1999, p. 196; Mamzer, 2004, p. 33-34). This is because archaeology is rooted in the philosophy of history, which is "an attempt to answer the question about the past that each epoch poses" (Mamzer, 2004, p. 190). Archaeology - like any other science - acts as a data provider, merely confirming previously assumed theses (Mamzer, Ostoja-Zagórski, 2007, p. 133). This archaeology found its fullest expression in the form of "ethnic myth". In an especially exposed way in archaeology, the ethnic problem is a modern problem for us: it is the implementation of postulates of modern European civilization, the interest of scientist and purely technical science. In fact, H. Mamzer has made "ethnicity" a leitmotif of his scientific activity, in particular by dealing with the topic of the ethnogenesis of Slavs for more than a century in the context of a dispute between indigenous and allochthonists (e.g. Mamzer 1999; 2000b, 2007, 2012a).

This article contributes to the criticism of extreme constructivism in the studies of the past. The clue of the following reasoning boils down to the basic distinction of the essentialisation of ethnicity as a phenomenon essentially external to archaeology, imposed on it by socio-historical reality, in which archaeology is implemented as a research practice, from the essenalization of heuristic categories, by means of which the variables provided by archaeological practice are operationalized, e.g. archaeological cultures. With all their complexity, these categories - e.g. archaeological cultures - constitute quasi-taxa in the Linnausz archaeology dictionary and as such constitute a specific research subject of archaeology as a separate field of science.

Criticism of ethnicity essentialism should be separated for significant methodological reasons from criticism of essentialism of archaeological specific heuristic categories, such as archaeological cultures. In fact, this problem results from the ambiguity of archaeology as a science that on the one hand belongs to the humanities, and on the other - has always claimed to be a representative of the exact sciences. It seems that the current paradigmatic disputes within archaeology result from this ambiguity of the status of the subject of research which archaeology deals with. Proponents of the constructivist paradigm strongly argue that archaeology is first and foremost a humanist science.

Although in their practice archaeologists are dealing with specific things - material correlates of culture - and their method is to lead to the strictest separation of the effects of subdeposition actions, in order to reach the philosophically understood thing itself, due to the metaphor of archaeology, all material reality is subject to textualization, everything is infinite by referring to something else. In fact, this is due to a too narrow understanding of the term "sub-position activities", because apart from the sphere of material transformations of archaeological material, the whole sphere of 
cultural transformations to which this material has been subject, will be subject and will be subject in the future falls out. It is true that constructivists assume that archaeology should break with the current historical perspective and seek help from anthropologists, because emphasizing the methods appropriate to one of these two scientific disciplines comes from this and not another vision of reality (Mamzer, 2004, p. 19; B. Werbart, 2000, p. 151-152; see also P. Urbańczyk, 2006; P. Barford, 2008, p. 126). By indicating that there is no direct relationship between the ethnos and the archaeological culture, they recognize the need to harness them in research into wider and more complex structures that take into account the relationship of power, politics, and kinship relationships.

This is the original sense of the metaphor of archaeology present in M. Foucault and only in this way can archaeology defend itself as a separate field of knowledge without falling into pure critique of existing ideology. Indeed, the original sense of the archaeological metaphor and its somewhat reflexive application in the field of archaeology are a fascinating problem. Paradoxically, the archaeological metaphor of M. Foucault in the form in which it is implemented by constructivists is the suicide of archaeology as a separate discipline of knowledge, moving to the position of helpers in the team of critics of existing ideology. Reflexively accepted by archaeologists contributes to the death of archaeology in the strict sense. The archaeological metaphor that Foucault devised, admiring the archaeology in the strict sense, to set it as an example for other sciences, in particular history, applied on the basis of archaeology, pupates itself into its opposite and becomes a poison. In fact, the key here is to change the direction of movement - the Foucaltian metaphor runs from things to their interpretations, while the constructivist application of the archaeological metaphor in the field of archaeology runs back - from interpretation to things. As if trying to correct the flash of genius, archaeologists unaware of their initial advantage, try to fix the error that is not there. And in this way they fall to the knees in a swamp of textualist interpretation. What's more - they are not aware of the paradoxes they fall into, hoping that in the assumed perspective they will be able to shake off errors that they themselves point out so-called modern European civilization/science. 